\title{
CHARACTERIZATION OF ADENOSINE DEAMINASE (ADA) IN HEMOLYMPH OF Biomphalaria glabrata
}

\author{
VALE, M. R., ${ }^{1}$ PEREIRA, R. V., ${ }^{1}$ ALMEIDA, S. M., ${ }^{1}$ \\ ALMEIDA, Y. M. ${ }^{2}$ and NUNES, S. F. L. C. ${ }^{1}$ \\ ${ }^{1}$ Laboratório de Bioquímica, Departamento de Fisiologia e Farmacologia, Faculdade de Medicina, \\ Universidade Federal do Ceará, Rua Cel. Nunes de Melo, 1127, CEP 60430-270, \\ Rodolfo Teófilo, Fortaleza, Ceará, Brazil \\ ${ }^{2}$ Laboratório de Parasitologia, Departamento de Patologia, Faculdade de Medicina, Universidade Federal do Ceará, \\ C.P. 3163, CEP 60430-270, Fortaleza, Ceará, Brazil \\ Correspondence to: Marcus Raimundo Vale, Universidade Federal do Ceará, Rua Cel. Nunes de Melo, 1127, \\ CEP 60430-270, Rodolfo Teófilo, Fortaleza, Ceará, Brazil, e-mail: mvale@ufc.br \\ Received June 23, 2003 - Accepted October 24, 2003 - Distributed May 31, 2005
}

(With 2 figures)

\begin{abstract}
Adenosine is an important signaling molecule for many cellular events. Adenosine deaminase (ADA) is a key enzyme for the control of extra- and intra-cellular levels of adenosine. Activity of ADA was detected in hemolymph of B. glabrata and its optimum assay conditions were determined experimentally. The $\mathrm{pH}$ variation from 6.2 to 7.8 caused no significant change in ADA activity. Using adenosine as a substrate, the apparent $\mathrm{Km}$ at pH 6.8 was $734 \mu \mathrm{mols} . \mathrm{L}^{-1}$. Highest activity was found at $37^{\circ} \mathrm{C}$. Standard assay conditions were established as being 15 minutes of incubation time, $0.4 \mu \mathrm{L}$ of pure hemolymph per assay, $\mathrm{pH} 6.8$, and $37^{\circ} \mathrm{C}$. This enzyme showed activities of $834 \pm 67 \mu \mathrm{mol} \cdot \mathrm{min}^{-1} \cdot \mathrm{L}^{-1}\left(25^{\circ} \mathrm{C}\right)$ and $2029 \pm 74 \mu \mathrm{mol} \cdot \mathrm{min}^{-1} \cdot \mathrm{L}^{-1}\left(37^{\circ} \mathrm{C}\right)$, exceeding those in healthy human serum by 40 and 100 times, respectively. Higher incubation temperature caused a decrease in activity of $20 \%$ at $43^{\circ} \mathrm{C}$ or $70 \%$ at $50^{\circ} \mathrm{C}$ for 15 minutes. The ADA lost from $26 \%$ to $78 \%$ of its activity when hemolymph was pre-incubated at $50^{\circ} \mathrm{C}$ for 2 or 15 minutes, respectively. Since the ADA from hemolymph presented high levels, it can be concluded that in healthy and fed animals, adenosine is maintained at low concentrations. In addition, the small variation in activity over the 6.2 to 7.8 range of $\mathrm{pH}$ suggests that adenosine is maintained at low levels in hemolymph even under adverse conditions, in which the $\mathrm{pH}$ is altered.
\end{abstract}

Key words: adenosine deaminase, Biomphalaria glabrata, hemolymph.

\section{RESUMO}

\section{Caracterização da adenosina desaminase (ADA) em Hemolinfa de Biomphalaria Glabrata}

A adenosina é uma molécula sinalizadora de muitos eventos celulares. A adenosina desaminase (ADA) é enzima-chave para o controle dos níveis intra e extracelulares de adenosina. A atividade da ADA foi detectada em hemolinfa de $B$. glabrata e suas condições ótimas de ensaio foram determinadas experimentalmente. A variação do $\mathrm{pH}$ de 6,2 a 7,8 não causou mudança significativa na atividade. $\mathrm{O} \mathrm{Km}$ aparente foi de $734 \mu$ moles. $\mathrm{L}^{-1}$, usando adenosina como substrato. A maior atividade foi encontrada usando $37^{\circ} \mathrm{C}$ como temperatura de incubação. As condições de ensaio-padrão foram então estabelecidas como sendo 15 minutos de tempo de incubação, $0,4 \mu \mathrm{L}$ de hemolinfa por ensaio, $\mathrm{pH}$ 6,8 e $37^{\circ} \mathrm{C}$ de temperatura de incubação. A enzima apresentou atividades de $834 \pm 67 \mu$ mols. $\min ^{-1} \cdot \mathrm{L}^{-1}\left(25^{\circ} \mathrm{C}\right)$ e $2029+74 \mu \mathrm{mols} \cdot \mathrm{min}^{-1} \cdot \mathrm{L}^{-1}\left(37^{\circ} \mathrm{C}\right)$, valores em torno de 40 e 100 vezes maiores que os níveis encontrados em soro de humanos sadios. Em temperaturas superiores, essa atividade cai $20 \%$ a $43^{\circ} \mathrm{C}$ e $70 \%$ a $50^{\circ} \mathrm{C}$, em 15 minutos. A ADA perde de $26 \%$ a $78 \%$ de sua atividade quando a hemolinfa é pré-incubada a $50^{\circ} \mathrm{C}$, de 2 a 15 minutos, respectivamente. Considerando os altos níveis de ADA 
encontrados pode-se inferir que, em animais sadios e alimentados, a adenosina é mantida em baixas concentrações na hemolinfa. Tendo a atividade da enzima permanecido constante ante a larga faixa de.pH testada, sugere-se que a ADA possa atuar com eficiência mesmo em situações adversas que determinem variações no $\mathrm{pH}$ da hemolinfa.

Palavras-chave: adenosina desaminase, Biomphalaria glabrata, hemolinfa.

\section{INTRODUCTION}

The nucleoside adenosine is both a metabolic precursor of nucleic acids and an important signaling molecule involved in regulating various physiological processes, mainly due to its inhibitory action on the immune system (Cohen et al., 2002; Okusa et al., 2000; Bouma et al., 1996; Firestein et al., 1995). Adenosine deaminase (ADA) participates in purine metabolism where it decomposes either adenosine or 2'-deoxy-adenosine, producing inosine or 2'deoxy-inosine, respectively. The physiological roles of $\mathrm{ADA}$ are directly related to control of adenosine concentrations in intra- and extra-cellular space. More recently, ADA was found to be implicated in an extraenzymatic activity (ecto-ADA) by binding to CD26 in the surface of lymphocytes, apparently functioning as an extra-cellular signaling molecule (Franco et al., 1998). This enzyme has become an object of great interest also because ADA deficiency causes severe combined immunodeficiency disease (SCID) (Hirschhorn, 1995); in addition, it is an important marker for tuberculosis (Burgess et al., 2001; Valdes et al., 1995; Valdes et al., 1996; Chalhoub et al., 1996).

This enzyme has been studied in a variety of animals like rats (Blackburn et al., 2000), mice (Singh \& Sharma, 1998), dogs (Altug \& Agaoglu, 2000), mosquitoes (Ribeiro et al., 2001), flies (Charlab et al., 2000), and märine mollusks (Chen et al., 2000). Recently, our laboratory has characterized ADA iso-forms from caprine tissues (Rodrigues et al., 2000).

Since ADA plays significant roles in the immune systems of several animals, we have directed our study to this enzyme in infection models. One of these is infection of the mollusk Biomphalaria glabrata by Schistosoma mansoni, which can also infect man, and in some areas causes a significant public health problem (for a review, see Morgan et al., 2001).
Although a large number of papers have focused on $B$. glabrata, nothing has yet been published about ADA in its tissues. This work describes some characteristics of ADA activity in this mollusk's hemolymph, and was undertaken as the first step in investigating the possible role of ADA during infection of $B$. glabrata by $S$. mansoni.

\section{MATERIAL AND METHODS}

\section{Collection of B. glabrata hemolymph}

Animals were obtained from the Biological Sciences Institute, Federal University of Minas Gerais, Brazil, and maintained at $25^{\circ} \mathrm{C}$ in the Parasitology Laboratory of Faculty of Medicine, Federal University of Ceará, Brazil.

Fed animals with shell diameters of between 15 and $18 \mathrm{~mm}$ were used. The hemolymph was obtained by perforating the shells with a collector constructed in our laboratory. This device consists of an eppendorf tube with a rubber stopper through which were two injection needles, one linked by tubing to another needle (to perforate the shell), which in turn is connected to a $10 \mathrm{ml}$ syringe (to create negative pressure in the system).

After collection, the hemolymph was centrifuged at $10,000 \times \mathrm{g}\left(4^{\circ} \mathrm{C}\right)$. The supernatant was diluted 50 times in cold phosphate buffer $\left(50\right.$ mmol.L $\mathrm{L}^{-1}, \mathrm{pH}$ 6.8 ) and used for ADA determination.

\section{ADA assay}

The ADA assay was based on the quantification of ammonium formed by deamination of adenosine catalysed by this enzyme (Giusti, 1974). Due to high levels of ADA activity in the hemolymph, the latter was diluted 50 times in assay buffer (see below) in order to maintain the volumes by the method. Thus, $20 \mu \mathrm{L}$ of diluted hemolymph corresponds to $0.4 \mu \mathrm{L}$ of pure hemolymph. The sample assay contained $200 \mu \mathrm{L}$ of adenosine $\left(2.2 \mathrm{mmol} . \mathrm{L}^{-1}\right)$ and $20 \mu \mathrm{L}$ of 
hemolymph $(1: 50, \mathrm{v}: \mathrm{v})$, both diluted in phosphate buffer, 50 mmol. $\mathrm{L}^{-1}$, pH 6.8 (assay buffer). This was incubated at $37^{\circ} \mathrm{C}$ for 15 minutes. The reaction was interrupted by the addition of $600 \mu \mathrm{L}$ of phenol/ sodium nitroprussiate $\left(106 / 0.17 \mathrm{mmol} . \mathrm{L}^{-1}\right)$, followed by $600 \mu \mathrm{L}$ of alcaline sodium hypochlorite (11 mmol.L $\mathrm{L}^{-1} \mathrm{NaOCl}$ in $125 \mathrm{mmol} . \mathrm{L}^{-1} \mathrm{NaOH}$ ), and incubated for 30 minutes at $37^{\circ} \mathrm{C}$. A blue color developed due to formation of indophenol blue; absorbance at $268 \mathrm{~nm}$ was proportional to the concentration of ammonium released from adenosine. In order to discount spontaneous, non-enzymatic adenosine deamination, a control tube containing only adenosine was run in parallel, but the diluted hemolymph $(20 \mu \mathrm{L})$ was added after addition of phenol reagent. For quantification of ammonium, a standard tube containing a known concentration of ammonium sulphate $\left(200 \mu \mathrm{L}-75 \mu \mathrm{mol} . \mathrm{L}^{-1}\right)$ and a blank tube containing only buffer to discount background ammonium in the buffer $(200 \mu \mathrm{L})$, were submitted to the same conditions as above, including the addition of hemolymph $(20 \mu \mathrm{L})$ after the phenol/ nitroprussiate reagent.

The ADA thermostability was studied in two ways. First, the effect of assay temperature was analyzed by incubating the hemolymph $(20 \mu \mathrm{L}-1: 50$ $\mathrm{v}: \mathrm{v})$ in the presence of adenosine $\left(2.2 \mathrm{mmols} . \mathrm{L}^{-1}\right)$ for 15 minutes from 25 to $50^{\circ} \mathrm{C}$. Second, the same effect was analyzed by pre-incubating the hemolymph alone $(1: 50, v: v)$ from 0 to 15 minutes at $50^{\circ} \mathrm{C}$, after which the ADA activity was measured.

The apparent $\mathrm{Km}$ value of ADA in hemolymph was determined based on the curve of the substrate calculated by a Lineweaver-Burk plot. The assay tubes containing $200 \mu \mathrm{L}$ of adenosine in assay buffer (concentrations from 0 to $1 \mathrm{mmol} . \mathrm{L}^{-1}$ ) and $20 \mu \mathrm{l}$ of hemolymph (1:50, v:v, in assay buffer) were incubated at $37^{\circ} \mathrm{C}$ for 15 minutes. The quantification of ammonium was performed as described above.

The $\mathrm{pH}$ variation effect on ADA activity was tested under standard conditions, i.e., adenosine (200 $\left.\mu \mathrm{L}-2.2 \mathrm{mmol} . \mathrm{L}^{-1}\right)$ and hemolymph $(20 \mu \mathrm{L}-1: 50$, v:v), both diluted in an assay buffer having different $\mathrm{pH}$ (from 6 to 8), at 15 minutes of incubation time.

\section{RESULTS}

Standard conditions of hemolymph ADA were defined by studying ADA activity dependence on: time of incubation, $\mathrm{pH}$, enzyme concentration, and substrate concentration. Figure 1A shows enzyme activity dependence on incubation time (0-60 minutes). Fifteen minutes was adopted as the standard incubation time throughout the work because it relates to a linear region of the curve and presents reliable absorbance values.

The effect of $\mathrm{pH}$ on ADA is presented in Fig. 1B. As can be seen, there were no statistically significant differences between ADA measured in the $\mathrm{pH}$ range of 6.2 to 7.8 (Tukey test). However, $\mathrm{pH} 6.8$ was adopted as the standard condition because it approximates ADA optimum $\mathrm{pH}$ in other animals and presents reliable absorbance values (Valdes et al., 1996; Rodrigues et al., 2000; Altug et al., 2000).

The gradual increase of hemolymph volume in the assay caused a linear increase in ADA activity, as demonstrated in Fig. 1C. The standard volume of $20 \mu \mathrm{L} \quad(1: 50$, equivalent to $0.4 \mu \mathrm{L}$ pure hemolymph in the figure; see methods) was chosen because it lays in the linear region of the curve, affords reliable spectrophotometer readings, and allows enough room for growing volume of substrate in determining the apparent $\mathrm{Km}$ (see below).

The $\mathrm{Km}$ and maximum velocity of $\mathrm{ADA}$ were estimated using a Lineweaver-Burk plot by the variation of substrate concentration from 0 to 2.1 mmoles. $\mathrm{L}^{-1}$, as shown in Fig. 1D. The curve equation $(\mathrm{y}=0.0002042 . \mathrm{x}+0.0003723)$ gave an apparent $\mathrm{Km}$ of $734 \mu \mathrm{mol} . \mathrm{L}^{-1}$ and Vmax of 2686 $\mu \mathrm{mol} \mathrm{NH} \mathrm{Nin}^{-1} \cdot \mathrm{L}^{-1}$ (s.e.m., $n=6$ ).

The increase of incubation temperature from 25 to $37^{\circ} \mathrm{C}$ caused an increase in enzyme activity of from $834 \pm 67$ to $2029 \pm 74 \mu \mathrm{mol} . \mathrm{min}^{-1}$. $\mathrm{L}^{-1}$ (s.e.m., $n=8$ ). However, further increase produced activity decrease (Fig. 2A). Enzyme activity decay was observed when the incubation temperature was $43^{\circ} \mathrm{C}$ or $50^{\circ} \mathrm{C}$ (about $20 \%$ or $70 \%$, respectively). The adopted incubation temperature was $37^{\circ} \mathrm{C}$ because it resulted in the highest activity.

The pre-incubation of hemolymph alone at $50^{\circ} \mathrm{C}$ for up to 15 minutes caused enzyme activity decay. Figure $2 \mathrm{~B}$ shows that within 2 minutes of preincubation at $50^{\circ} \mathrm{C}$, the $\mathrm{ADA}$ lost about $26 \%$ of its activity (from $1733+123 \mu \mathrm{mol} \cdot \mathrm{min}^{-1} \cdot \mathrm{L}^{-1}-$ s.e.m., $n=8$, at $\mathrm{t}=0$ to $1278 \pm 119 \mu \mathrm{mol} \cdot \mathrm{min}^{-1} \cdot \mathrm{L}^{-1}$, - s.e.m., $n=8$, at $2 \mathrm{~min}$ ) and $78 \%$ when it was preincubated for 15 minutes $\left(375 \pm 66 \mu\right.$ mol. $\mathrm{min}^{-1} \cdot \mathrm{L}^{-1}-$ s.e.m., $n=8)$. 

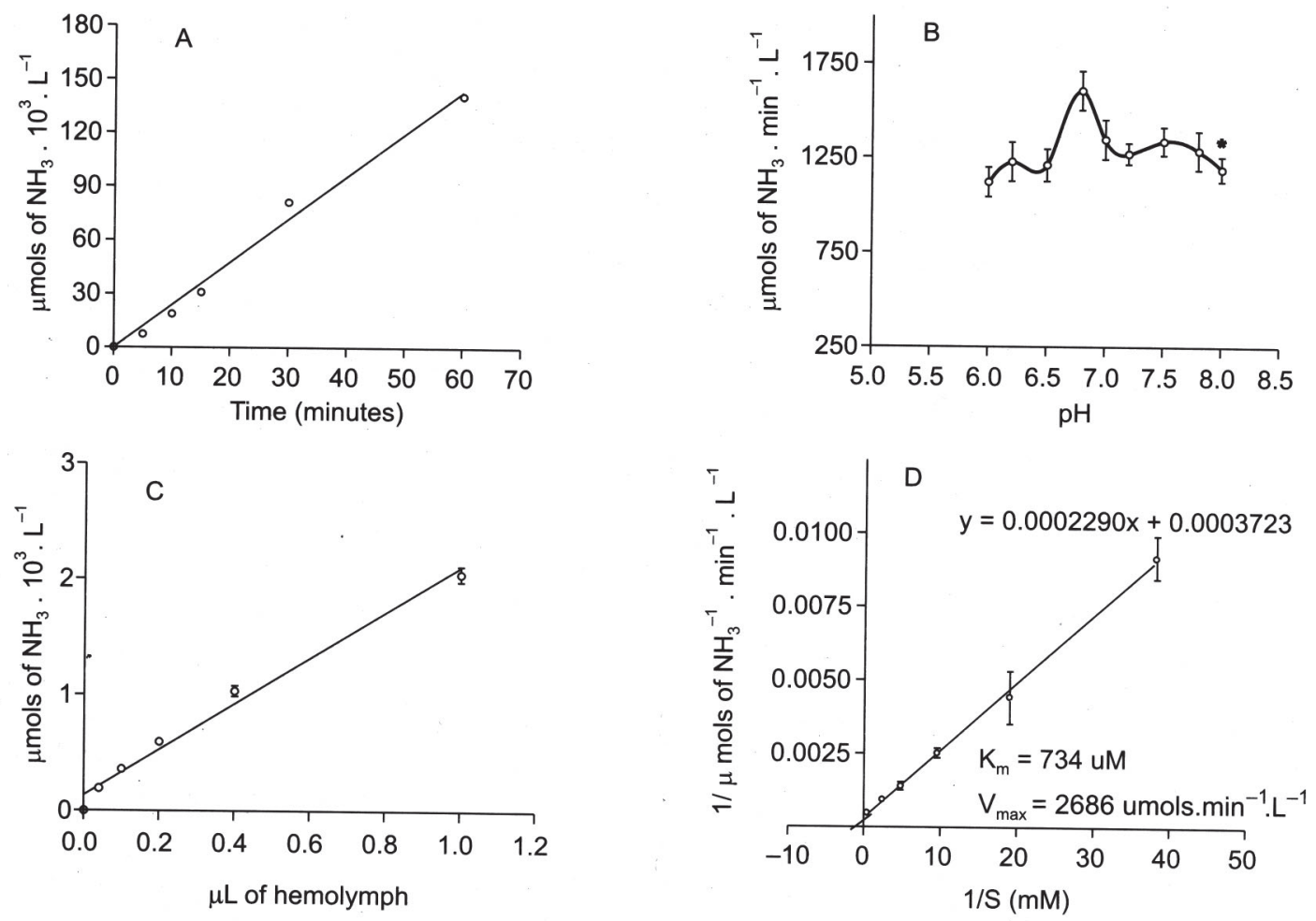

Fig. 1 - Basic parameters of ADA activity in hemolymph of B. glabrata. A: variation of ADA activity as a function of incubation time. $\mathrm{B}$ : variation of $\mathrm{ADA}$ activity as a function of $\mathrm{pH}$. $\mathrm{C}$ : variation of $\mathrm{ADA}$ activity as a function of hemolymph volume in the assay. $\mathrm{D}$ : Lineweaver-Burk plot of ADA activity for the estimation of $\mathrm{Km}$ and Vmax. The equation found was: $\mathrm{Y}=0.0002290 \mathrm{x}+0.0003723$. The standard conditions were as follows: $\mathrm{pH} 6.8$, incubation temperature $=37^{\circ} \mathrm{C}$, volume of pure hemolymph $=0.4 \mu \mathrm{L}$, adenosine $=1$ mmol.L $\mathrm{L}^{-1}, 15$ minutes of incubation time. The values represent the mean \pm s.e.m., $n=6-8$.
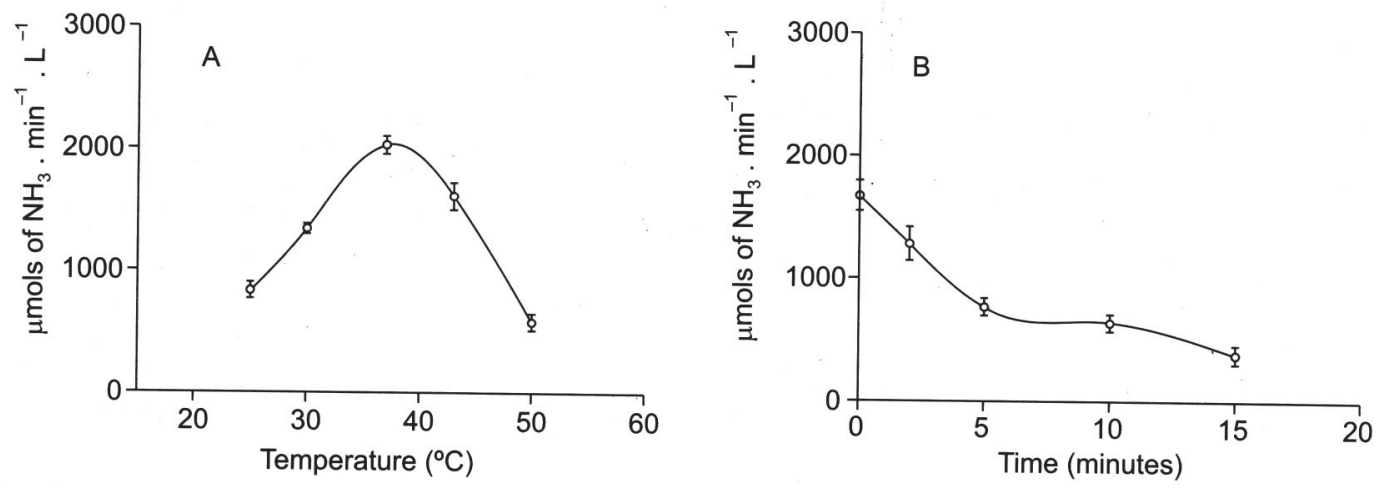

Fig. 2 - Effect of temperature on ADA activity in hemolymph. A: ADA activity as a function of temperature (incubation time - 15 min.). B: ADA activity in hemolymph pre-incubated at $50^{\circ} \mathrm{C}$ from 0 to 15 minutes. After pre-incubation, ADA activity was assayed under standard conditions. Standard conditions were as follows: $\mathrm{pH} 6.8$, incubation temperature $=37^{\circ} \mathrm{C}, 0.4 \mu \mathrm{L}$ hemolymph, adenosine $=1 \mathrm{mmol} . \mathrm{L}^{-1}$, 15 minutes of incubation time. The values represent the mean \pm s.e.m., $n=8$. 


\section{DISCUSSION}

Under the conditions in which this work was done, the highest activity for hemolymph ADA in B. glabrata was observed at $37^{\circ} \mathrm{C}$. However, the ambient temperature of the laboratory where the animals were kept was around $25^{\circ} \mathrm{C}$, which should be the working temperature of the enzyme in the animal. Using $25^{\circ} \mathrm{C}$ as the assay temperature, the ADA of the hemolymph presented activity about 40 times higher than ADA in human serum, which is $10-20 \mu$ mols. $\mathrm{min}^{-1}$. $\mathrm{L}^{-1}$ (Giusti, 1974), and other animal sera assayed at $37^{\circ} \mathrm{C}$ (Sathar et al., 1999; Rodrigues et al., 2000). This could mean that in B. glabrata adenosine concentrations in hemolymph are maintained at very low levels.

Even though little or nothing is known about the role of adenosine in $B$. glabrata, by taking into account the role of this nucleoside in man and most animals, one may suggest that even a small increase of adenosine level can trigger important events in this animal. Thus, this level has to be strongly controlled. In addition, the large working $\mathrm{pH}$ range of ADA in hemolymph could also be interpreted as a factor involved in effectively controlling adenosine levels, even under extreme metabolic conditions.

It should be added that preliminary results of our laboratory work have demonstrated the existence of ADA iso-forms in the hepatopancreas of B. glabrata (Nunes et al., 2002).

The data obtained in this work represents a contribution to the study of ADA characteristics in B. glabrata, since it has determined some basic parameters of enzyme kinetics. These include incubation_time, $\mathrm{pH}$ variation effects, apparent $\mathrm{Km}$ and Vmax, besides its thermostability.

The above data has encouraged us to go on with this investigation, and to continue the search for ADA iso-forms in other tissues of the mollusk.

Aknowledgements - The second author thanks the Fundação Cearense de Apoio ao Desenvolvimento Científico e Tecnológico (FUNCAP) for a scholarship. We are indebted to Dr. Vietla S. Rao for reviewing the manuscript.

\section{REFERENCES}

ALTUG, N. \& AGAOGLU, T., 2000, Serum adenosine deaminase in dogs: its importance in experimental liver intoxication. Isr. Vet. Med., 55:130-134.
BLACKBURN, M. R., VOLMER, J. B., THRASHER, J. L., ZHONG, H., CROSBY, J. R., LEE, J. J. \& KELLEMS, R. E., 2000, Metabolic consequences of adenosine deaminase deficiency. in mice are associated with defects in alveogenesis, pulmonary inflammation, and airway obstruction. J. Exp. Med., 192: $159-170$

BOUMA, M. G, VAN DEN WILDENBERG F. A. \& BUURMAN, W. A., 1996, Adenosine inhibits cytokine release and expression of adhesion molecules by activated human endothelial cells. Am. J. Physiol. Cell. Physiol., 270: C522-C529.

BURGESS, L. J., SWANEPOEL, C. G \& TALJAARD, J. J., 2001, The use of adenosine deaminase as a diagnostic tool for peritoneal tuberculosis. Tuberculosis (Edinb), 81(3): 243248

CHALHOUB, M., CRUZ, A. A., MARCILIO, C. \& NETTO, M. B., 1996, Value of determining the activity of adenosine deaminase (ADA) in the differential diagnosis of pleural effusions. Rev. Assoc. Med. Bras., 42: 139-146.

CHARLAB, R., ROWTON, E. D. \& RIBEIRO, J. M., 2000, The salivary adenosine desaminase from the sand fly Lutzomyia longipalpis. Exp. Parasitol., 95: 45-53.

CHEN, X. Y., UCHIDA, H., MIGITAKA, Y., HAYASHI, T. \& UWAJIMA, T., 2000, Isolation and characterization of adenosine deaminase in the adduct or muscle of marine bivalve molluscs. Fish. Sci., 66: 748-754.

COHEN, E. S., LAW, W. R., EASINGTON, C. R., CRUZ, K. Q., NARDULLI, B. A., BALK, R. A., PARRILLO, J. E. \& HOLLENBERG, S. M., 2002, Adenosine deaminase inhibition attenuates microvascular dysfunction and improves survival in sepsis. Am. J. Respir. Crit. Care Med., 166: 16-20.

FIRESTEIN, G. S., BULlOUGH, D. A., ERION, M. D., JIMENEZ, R., RAMIREZ-WEINHOUSE, M., BARANKIEWICK, J., SMITH, C. W., GRUBER, H. E. \& MULLANE, K. M., 1995, Inhibition of neutrophil adhesion by adenosine and an adenosine kinase inhibitor. J. Immunol., 154: 326-334.

FRANCO, R., VALENZUELA, A., LLUIS, C. \& BLANCO, J., 1998, Enzymatic and extraenzymatic role of ecto-adenosine deaminase in lymphocytes. Immunol. Rev., 161: 27-42.

GIUSTI, G., 1974, Adenosine deaminase. pp. 1092-1099. In: H. U. Bergmeyer (ed.), Methods of enzymatic analysis. Academic Press, New York.

HIRSCHHORN, R., 1995, Adenosine deaminase deficiency: molecular basis and recent developments. Clin. Immunol., 76: S219-S227.

MORGAN, J. A., DEJONG, R. J., SNYDER, S. D., MKOJI, G. M. \& LOKER, E. S., 2001, Schistosoma mansoni and Biomphalaria: past history and future trends. Parasitol., 123 Suppl: S211-28.

NUNES, S. F. L. C., PEREIRA, R. V., VASCONCELOS, M. P., ALMEIDA, Y. M. \& VALE, M. R., 2002, Isoformas de adenosina desaminase (ADA) em Biomphalaria glabrata. Anais da Reunião Anual da Federação das Sociedades de Biologia Experimental (FeSBE). Resumo 19.016. 
OKUSA, M. D., LINDEN, J., HUANG, L., RIEGER, J. M., MACDONALD, T. L. \& HUYNH, L. P., 2000, A2A adenosine receptor-mediated inhibition of renal injury and neutrophil adhesion. Am. J. Physiol. - Renal Physiol, 279(5): F809-818.

RIBEIRO, J. M. C., CHARLAB, R. \& VALENZUELA, J. G., 2001, The salivary adenosine desaminase activity of the mosquitoes Culex quinquefasciatus and Aedes aegypti. J. Exp. Biol., 204: 2001-2010.

RODRIGUES, L. F. S., FREIRE, G. H. \& VALE, M. R., 2000, Multiple iso-forms of caprine adenosine desaminase. Isr. Vet. Med., 55: 135-138.

SATHAR, M. A., UNGERER, J. P., LOCKHAT, F., SIMJEE, A. E. \& GOUWS, E., 1999, Elevated adenosine deaminase activity in patients with HIV and tuberculous peritonitis. Eur. J. Gastroenterol. Hepatol., 11: 337-342.
SINGH, L. S. \& SHARMA, R., 1998, Alloxan diabetes regulates adenosine deaminase activity in mice: tissue- and age-specific correlation. Biochem. Mol. Biol. Int., 46: 55-61.

VALDES, L., ALVAREZ, D., SAN JOSE, E., JUANATEY, J. R., POSE, A., VALLE, J. M., SALGUEIRO, M. \& SUAREZ, J. R., 1995, Value of adenosine deaminase in the diagnosis of tuberculous pleural effusions in young patients in a region of high prevalence of tuberculosis. Thorax., 50: 600-603.

VALDES, L., SAN JOSE, E., ALVAREZ, D. \& VALLE, J. M., 1996, Adenosine deaminase (ADA) isoenzyme analysis in pleural effusions: diagnostic role and relevance to the origin of increased ADA in tuberculous pleurisy. Eur. Resp. J., 9: 747-751. 